\title{
The varying clinical presentations of peripheral ossifying fibroma: A report of three cases
}

\section{As diversas apresentações de fibroma ossificante periférico: relato de três casos}

\begin{abstract}
Purpose: Gingival growths are one of the most frequently encountered lesions in the oral cavity. Most of these lesions are innocuous, but some do have malignant potential. Different lesions with similar clinical presentations make it difficult to arrive at a correct diagnosis. One of the infrequently occurring gingival lesions is peripheral ossifying fibroma (POF). Lesions with histological features similar to POF have been given various names, adding to the confusion. We report the varied clinicopathological features of 3 cases of POF, discuss the contentious nomenclature and investigate the possible etiopathogenesis of this disease.

Case description: Three cases of gingival growths (POF) are reported. Two of the lesions occurred in the maxillary anterior region, while the third occurred in the mandibular posterior region. Two of the cases showed radiographic evidence of bone loss. An excision biopsy was performed in all three cases.

Conclusion: Because the rate of recurrence for peripheral ossifying fibroma is $8 \%$ to $20 \%$, close postoperative monitoring is required. It is also necessary to use consistent and specific nomenclature in the literature to avoid confusion and the loss of important data.
\end{abstract}

Key words: Fibroma; gingival overgrowth; peripheral ossifying fibroma

\section{Resumo}

Objetivo: Crescimentos gengivais são uma das doenças mais frequentemente encontradas na cavidade oral. A maioria dessas lesões são inócuas, mas alguns têm potencial maligno. Lesões diferentes com apresentações clínicas semelhantes tornam difícil um diagnóstico correto. Uma das lesões gengivais que ocorre raramente é o fibroma ossificante periférico (FOP). Lesões com características histológicas semelhantes ao FOP têm nomenclatura diferente, aumentando a confusão. Este artigo relata as características clinico-patológicos de 3 casos de fibroma ossificante periférico.

Descrição do caso: Três casos de FOP são relatados. Duas das lesões ocorreram na região anterior da maxila, enquanto a terceira localizava-se na região posterior da mandíbula. Dois dos casos apresentaram evidências radiográficas de perda óssea. Biópsia excisional foi realizada em todos os três casos.

Conclusão: Como a taxa de recorrência para FOP é de $8 \%$ a 20\%, o monitoramento pósoperatório é necessário. Deve-se utilizar nomenclatura consistente e específica na literatura para evitar confusão e perda de dados importantes.

Palavras-chave: Fibroma; crescimento gengival; fibroma ossificante periférico

\author{
Sumona Pal a \\ Shruthi Hegde ${ }^{b}$ \\ Vidya Ajilab
}
- Department of Oral Medicine and Radiology, Haldia Institute of Dental Sciences and Research, West Bengal, India.
${ }^{b}$ Department of Oral Medicine and Radiology, AB Shetty Memorial Institute of Dental Sciences, Nitte University Mangalore, India.

\author{
Correspondence: \\ Sumona Pal \\ Department of Oral Medicine and Radiology, \\ Haldia Institute of Dental Sciences and Research \\ West Bengal - India \\ E-mail: sumona_capri@yahoo.co.in
}

Received: November 23, 2011

Accepted: August 16, 2012

Conflict of Interests: The authors state that there are no financial and personal conflicts of interest that could have inappropriately influenced their work.

Copyright: (C) 2012 Pal et al.; licensee EDIPUCRS. This is an Open Access article distributed under the terms of the Creative Commons AttributionNoncommercial-No Derivative Works 3.0 Unported License. 


\section{Introduction}

Gingival growths are one of the most frequently encountered lesions in the oral cavity. Most of these lesions, such as irritational fibroma, pyogenic granuloma, peripheral ossifying fibroma and peripheral giant cell granuloma, are innocuous and rarely present with aggressive features. In the majority of cases, these lesions are the result of trauma or chronic irritation. One of the infrequently occurring gingival lesions is peripheral ossifying fibroma (POF). Peripheral ossifying fibroma is a focal, reactive, non-neoplastic tumorlike growth of the soft tissue that often arises from the interdental papilla (1). This paper highlights the diverse clinical and histopathological presentations of peripheral ossifying fibroma through three cases encountered in our practice.

\section{Case Description}

Case 1: A 31-year-old female reported to the outpatient department with a slow-growing gingival growth in the right posterior mandibular tooth region that had been present for 6 months. The patient's history revealed that a local dentist had excised the lesion and completed oral prophylaxis 3 months previously. The growth reoccurred in the same area following the excision. An intraoral examination revealed a sessile growth in the interdental papilla close to 46 . The growth measured approximately $2 \mathrm{~cm} \times 1.5 \mathrm{~cm}$ in size, was not tender and was firm in consistency (Fig. 1A). The surface was pinkish red in color and granular. A radiographic examination showed mild crestal bone loss in the region of 47 and 48 (Fig. 2A). An excision biopsy was performed. A histopathological examination revealed a covering of partially parakeratinized stratified squamous epithelium proliferating into the underlying connective tissue. Part of the section was ulcerated. The underlying connective tissue was cellular and edematous with several small blood vessels and showed a mild chronic inflammatory infiltrate. An area of trabecular bone formation was also observed (Fig. 3A). A histopathological examination revealed features of POF.

Case 2: A 45-year-old male reported to the department with the complaint of a 15-year-old growth in the upper front tooth region. The patient's medical and dental history did not contribute to the diagnosis. An intraoral examination revealed a solitary, well-defined pedunculated growth in the maxillary anterior region (Fig. 1B). The growth measured $3 \mathrm{~cm} \times 3 \mathrm{~cm}$ in size. The surface of the growth appeared slightly rough, with the growth appearing erythematous in the upper half and a pale pink color in the lower half. A palatal displacement of 21 was observed. On palpation, the growth was not tender and was firm in consistency. An intraoral radiograph showed a soft tissue shadow in the region of 21 and 22, with a few radio-opaque specks throughout the lesion (Fig. 2B). Periodontal bone loss was noted up to the apical third of 21, 22 and 11 . The growth was surgically excised, and 11 and 21 were extracted. Histopathological analysis showed a hyperparakeratinized stratified squamous epithelium that was ulcerated in one area. The connective tissue was densely fibrocellular. Several irregular basophilic calcified areas were noted (Fig. 3B). These features were suggestive of POF.

Case 3: A 23-year-old female reported to the department with a 6-month-old recurrent growth in the upper front tooth region. A solitary, well-defined pedunculated growth measuring $1 \mathrm{~cm} \times 1.5 \mathrm{~cm}$ was observed on the palatal surface of the maxillary anterior region (Fig. 1C). The surface appeared slightly rough and erythematous. On palpation, the growth was not tender and was firm in consistency. An intraoral radiograph did not show any abnormalities (Fig. 2C). An excision biopsy was performed. Histopathology showed a hyperplastic epithelial lining; the underlying connective tissue showed a dense bundle of collagen fibers and a large number of fibroblasts. Osteoid areas and cementicles were also observed (Fig. 3C). The histopathological features supported a diagnosis of POF.

\section{Discussion}

In 1982, Gardner coined the term peripheral ossifying fibroma for a lesion that is reactive in nature and is not the extraosseous counterpart of a central ossifying fibroma (COF) of the maxilla and mandible (2).

The use of a variety of terminologies for POF indicates a great amount of confusion regarding the lesion and its pathogenesis. Ossifying fibroid epulis, peripheral fibroma with calcification, peripheral cemento-ossifying fibroma, calcifying fibroma, peripheral cementifying fibroma, ossifying fibro-epithelial polyp, peripheral fibroma with osteogenesis, peripheral fibroma with cementogenesis, peripheral fibroma with calcification, calcifying or ossifying fibrous epulis and calcifying fibroblastic granuloma are all terms that have been used to refer to peripheral ossifying fibroma (3).

There are two types of ossifying fibromas: the central type and the peripheral type. The central type arises from the endosteum or the periodontal ligament adjacent to the root apex and causes the expansion of the medullary cavity. The peripheral type occurs solely on the soft tissues covering the tooth-bearing areas of the jaws (4). COF was found to exhibit increased proliferative activity compared to POF (5).

The term 'peripheral odontogenic fibroma' has also been used to describe peripheral ossifying fibroma but should be avoided, as peripheral odontogenic fibroma (POdF) has been designated by the World Health Organization (WHO) as the rare and extraosseous counterpart of central odontogenic fibroma (COdF) and histologically presents as a fibroblastic neoplasm containing odontogenic epithelium (6).

Regardless of the resemblance in terminology, POF is a completely separate entity from peripheral odontogenic fibroma and central ossifying fibroma (Table 1). 

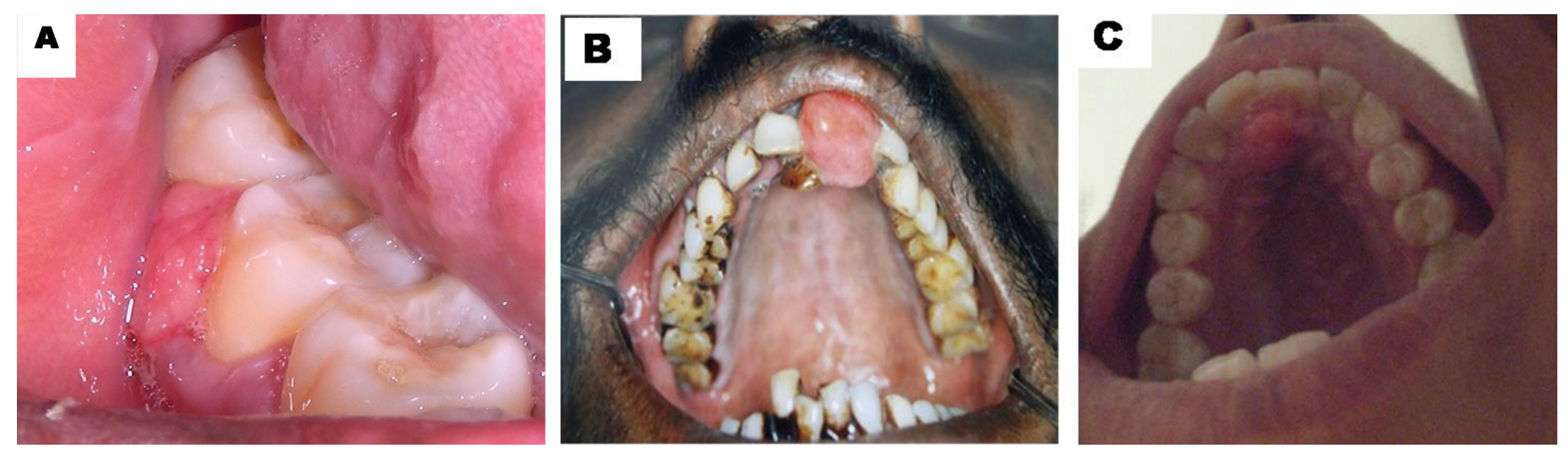

Fig. 1. Intraoral photograph showing gingival growth in case $1(\mathrm{~A})$, case 2 (B), and case 3 (C).
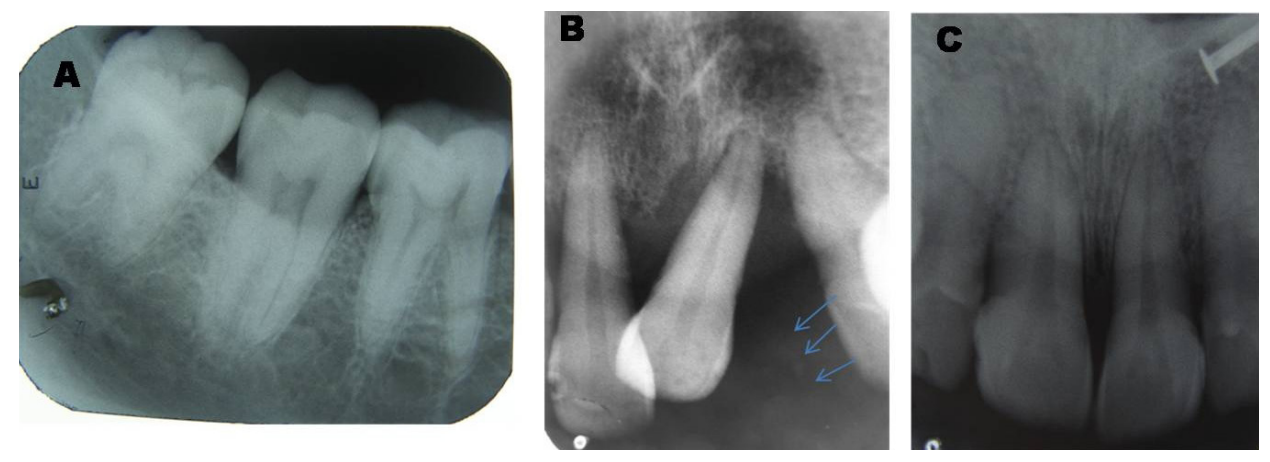

Fig. 2. IOPAR showing mild crestal bone loss in case 1 (A), mesially migrated 21 , alveolar bone loss and soft tissue shadow with specks of calcification in case 2 (B), and no observable variation in case $3(\mathrm{C})$.
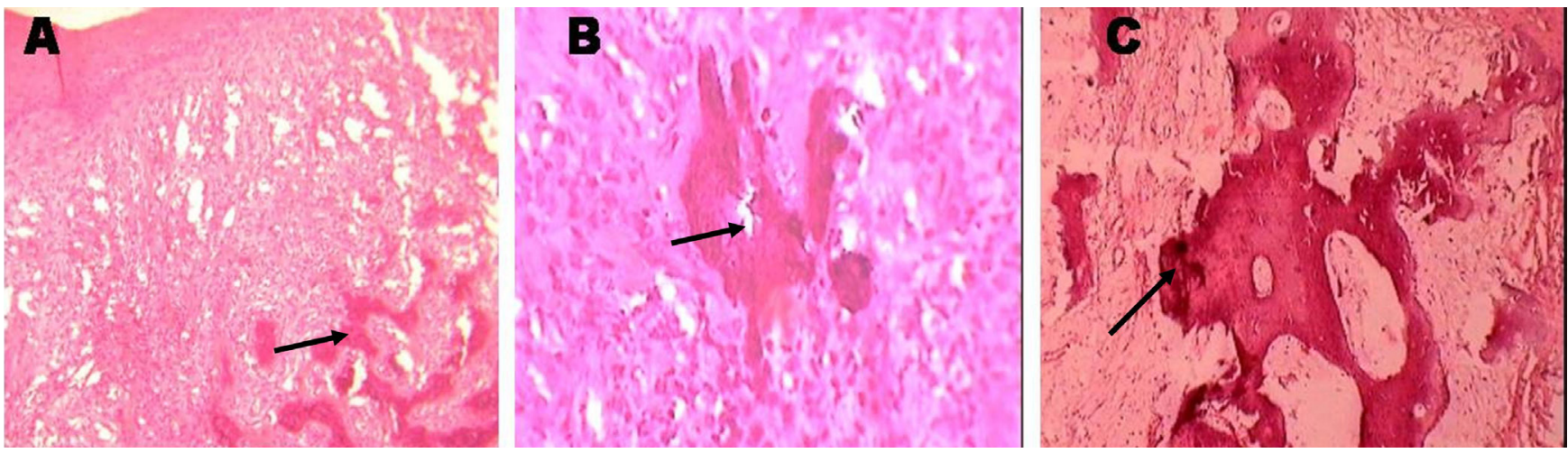

Fig. 3. Photomicrograph shows partially parakeratinised stratified squamous epithelium, with areas of trabecular bone/cementicle/calcification formation in connective tissue in case 1 (A), case 2 (B), and case $3(C)$.

Table1. Differences between POF, COF, POdF, COdF

\begin{tabular}{|c|c|c|c|c|}
\hline & $\begin{array}{l}\text { Peripheral ossifying } \\
\text { fibroma (POF) }\end{array}$ & $\begin{array}{l}\text { Central ossifying } \\
\text { fibroma (COF) }\end{array}$ & $\begin{array}{l}\text { Peripheral odontogenic } \\
\text { fibroma (POdF) }\end{array}$ & $\begin{array}{l}\text { Central odontogenic } \\
\text { fibroma (COdF) }\end{array}$ \\
\hline Nature & Reactive lesion & Fibro-osseous lesion & Odontogenic tumor & Odontogenic tumor \\
\hline Site & Mostly on gingiva & $\begin{array}{l}\text { Widespread lesion in the long } \\
\text { bones but may also occur in } \\
\text { the skull and jaw bones }\end{array}$ & $\begin{array}{l}\text { Gingiva, but occurrence } \\
\text { is rare }\end{array}$ & $\begin{array}{l}\text { Jaw bones; very rare } \\
\text { occurrence }\end{array}$ \\
\hline Classification & No subtypes & $\begin{array}{l}\text { Two types: } \\
\text { 1) Psammomatoid } \\
\text { 2) Juvenile type }\end{array}$ & $\begin{array}{l}\text { Histologically the same as } \\
\text { COdF; containsodontogenic } \\
\text { epithelium }\end{array}$ & $\begin{array}{l}\text { Two types: } \\
\text { 1) Simple type } \\
\text { (without mineralization) } \\
\text { 2) WHO type } \\
\text { (with bone/cementum) }\end{array}$ \\
\hline Inter-relation & $\begin{array}{l}\text { Not the extraosseous } \\
\text { counterpart of COF }\end{array}$ & $\begin{array}{l}\text { Presents centrally - a separate } \\
\text { entity from POF }\end{array}$ & $\begin{array}{l}\text { Extraosseous counterpart } \\
\text { of } \mathrm{COdF}\end{array}$ & $\begin{array}{l}\text { Presents centrally - associated } \\
\text { with POdF }\end{array}$ \\
\hline
\end{tabular}


A polarizing microscopy study revealed that $73 \%$ of the 22 POF cases examined contained a fibrocellular connective tissue stroma surrounding the mineralized mass. The mineralized mass was comprised of woven bone in $50 \%$ of the cases, while $18 \%$ of the cases showed a combination of lamellar bone and cellular cementum, $18 \%$ of the cases comprised only cementum (cellular and acellular), and the remaining $13.6 \%$ exhibited a mixture of woven and lamellar bone. This evidence supports the theory that POF develops from the periodontal ligament/periosteum as undifferentiated mesenchymal cells with an inherent proliferative potential to form bone or cementum (7).

There is much uncertainty about the pathogenesis of this lesion. An origin in the periodontal ligament has been suggested. The reasons for considering the periodontal ligament as the origin of POF include the exclusive occurrence of POF in the gingiva (interdental papilla), the proximity of the gingiva to the periodontal ligament, and the presence of oxytalan fibers within the mineralized matrix of some lesions (3). The mature fibrous connective tissue proliferates excessively in response to gingival injury, gingival irritation, subgingival calculus or a foreign body in the gingival sulcus. Chronic irritation of the periosteal and periodontal membranes causes metaplasia of the connective tissue and initiates the formation of bone or dystrophic calcification. Thus, local irritants such as dental plaque, calculus, microorganisms, masticatory forces, ill-fitting dentures and poor quality restorations have been implicated in the etiology of POF (8). In addition, factors such as a higher prevalence in females and a peak occurrence in the second decade of life suggest hormonal influences (6). The rare manifestation of multicentric occurrence points to a role of genetics in the pathogenesis of this disease (3).

POF accounts for $3.1 \%$ of all oral tumors and $9.6 \%$ of gingival lesions $(6,9)$. This condition affects both genders but has been reported to occur at a higher rate in females (6). Whites (71\%) are more frequently affected than blacks (36\%) (10). POF may occur at various ages, but exhibits a peak incidence between the second and third decade (11).

Clinically, POF appears as a solitary nodular mass that is either pedunculated or sessile. The surface mucosal color ranges from red to pink, and the surface is frequently ulcerated. The mass usually arises from the interdental papilla. Lesions occur slightly more frequently in the maxillary arch (60\%) and the incisor cuspid region (50\%) (12). One of present cases showed a deviation from these preferred sites and occurred in the mandibular posterior region. Multicentric POF has been reported very rarely (3).

POF lesions usually measure less than $1.5 \mathrm{~cm}$ in diameter, but lesions with $6 \mathrm{~cm}$ and $9 \mathrm{~cm}$ diameters have been reported (11). All three of our cases exhibited lesions within $3 \mathrm{~cm}$ in diameter. POF can cause tooth separation, delayed tooth eruption or tooth migration $(13,14)$. The palatal displacement of teeth was observed in one of our cases.

Radiographically, POF can appear as diffuse radiopaque calcification, but not all lesions exhibit these characteristics. Only one of the three cases showed radiopaque specks over a soft tissue shadow. Occasionally, these lesions are associated with bone destruction (13).

POF is definitively diagnosed through a histopathological examination. The histopathological examination usually shows the following features: 1) benign fibrous connective tissue with varying fibroblast, myofibroblast and collagen content, 2) sparse to profuse endothelial proliferation, and 3) mineralized material that may represent mature, lamellar or woven osteoid, cementum-like material, or dystrophic calcifications. Acute or chronic inflammatory cell infiltration can also be observed in these lesions (3). The treatment of choice is complete surgical excision with the removal of the irritating factors.

Due to the high rate of recurrence ( $8 \%$ to $20 \%$ ), close postoperative monitoring is required in all cases of POF (1). POF recurs due to 1) the incomplete removal of the lesion, 2) the failure to eliminate local irritants and 3) difficulty in accessing the lesion during surgical manipulation as a result of the intricate location of the lesion (usually an interdental area) (7). None of our cases showed clinical signs of recurrence after 1 year of follow-up.

\section{Conclusions}

This report highlights the varied clinical and radiographic features of POF and discusses the contentious terminology used for this disease. Peripheral ossifying fibroma has a high rate of recurrence, making postoperative follow-up mandatory. It is also necessary to use consistent and specific nomenclature in the literature to avoid confusion and the loss of important data.

\section{References}

1. Farquhar T, Maclellan J, Dyment H, Anderson RD. Peripheral ossifying fibroma: a case report. J Can Dent Assoc 2008;7-:809-12.

2. Gardner DG. The peripheral odontogenic fibroma: an attempt at classification. Oral Surg Oral Med Oral Pathol 1982;54:40.

3. Kumar SK, Ram S, Jorgensen MG, Shuler CF, Sedghizadeh PP. Multicentric peripheral ossifying fibroma. J Oral Sci 2006;48:239-43.

4. Keluskar V, Byakodi R, Shah N. Peripheral ossifying fibroma. J Indian Acad Oral Med Radiol 2008;20:54-6.

5. Sousa SC, Mesquita RA, Araujo NS. Proliferative Activity in peripheral ossifying fibroma and ossifying fibroma. J Oral Pathol Med 1998;27:64-7

6. Kenney JN, Kaugars GE, Abbey LM. Comparison between the peripheral ossifying fibroma and peripheral odontogenic fibroma. J Oral Maxillofac Surg 1989;47:378-82. 
7. Shetty DC, Urs AB, Ahuja P, Sahu A, Manchanda A, Sirohi Y. Mineralized components and their interpretation in the histogenesis of peripheral ossifying fibroma. Indian J Dent Res $2011 ; 22: 56-61$.

8. Miller CS, Henry RG, Damm DD. Proliferative mass found in the gingiva. J Am Dent Assoc 1990;121:559-60.

9. Walters JD, Will JK, Hatfield RD, Cacchillo DA, Raabe DA. Excision and repair of the peripheral ossifying fibroma: a report of 3 cases. J Periodontol $2001 ; 72: 939-44$.

10. Cuisia ZES, Brannon RB. Peripheral ossifying fibroma - a clinical evaluation of 134 pediatric cases. Pediatr Dent $2001 ; 23: 245-8$.

11. Bodner L, Dayan D. Growth potential of peripheral ossifying fibroma. J Clin Periodontol 1987; 14:551-54.

12. Neville BW, Damm DD, Allen CM, Bouquot JE. Oral and Maxillofacial Pathology. $2^{\text {nd }}$ ed. Philadelphia:W.B. Saunders; 2005.p.451-2.

13. Delbem A, Cunha R, Silva J, Soubhia A. Peripheral cementoossifying fibroma in child. A follow-up of 4 years report of a case. Eur J Dent 2008;2:134-7.

14. Mishra MB, Bhishen KB and Mishra S. Peripheral ossifying fibroma. J Oral Maxillofac Pathol $2011 ; 15: 65-8$. 